\title{
METODE PENETAPAN MAQOSHID AL SYARIAH: Studi Pemikiran Abu Ishaq al Syatibi
}

\author{
Muhammad Aziz dan Sholikah ${ }^{2}$ \\ ${ }^{1}$ IAIN Syekh Nurjati Cirebon, email: mohaziv@yahoo.com \\ Telp: 085655432391 \\ 2IKIP PGRI Jember, email: sholikah86@gmail.com
}

\begin{abstract}
The spirit and core of anything prescribed in Islam are basically for human's benefits and preventing him from danger. Knowing and determining the intent and purpose of the prescribed law are definitely needed. This study describes the establishment method of maqashid sharia by reviewing the explanations of the Quran, al Sunnah and al Ijma. Particularly for worldly aspects, the approach is based on logical propositions as well as optimization of the use of correct ration and reasoning through a series of experiments, empirical habit, and a collection of hypotheses. Abu Ishaq Ibrahim al Syathibi sets maqashid al sharia through: 1) discerning the explicit expression of command and prohibition, 2) considering the context of each command and prohibition, 3) Noting all the derivatives, and 4) mapping for the absence of Sharia information.

Ruh dan inti setiap sesuatu yang disyariatkan oleh Islam pada dasarnya adalah untuk kemaslahatan manusia dan mencegah bahaya baginya. Mengetahui dan menentukan seluk beluk maksud dan tujuan atas pensyariatan suatu hukum tertentu sangat diperlukan. Kajian ini, menjelaskan cara menetapkan maqashid syariah melalui penelitian terhadap keterangan-keterangan dari al Quran, al Sunnah, dan al Ijma. Khusus aspek duniawi, pendekatannya berdasarkan dalil logika, serta optimalisasi penggunaan nalar dan rasio yang benar lewat serangkaian eksperimen, kebiasaan empirik, atau kumpulan hipotesa. Abu Ishaq Ibrahim al Syathibi menetapkan maqashid al syariah dengan cara: 1) Melihat ungkapan eksplisit perintah dan larangan, 2) Memperhatikan konteks setiap perintah dan larangan, 3) Memperhatikan semua turunan hakikatnya, dan 4) Memetakan atas ketiadaan keterangan syar'i.
\end{abstract}

Keywords: maqashid al sharia, Abu Ishaq al Syathibi, thuruq itsbat al maqashid, al muwafaqat

Ulul Albab Volume 14, No.2 Tahun 2013 


\section{Pendahuluan}

Maqashid al Syariah, merupakan ruh, spirit, dan hakikat dari disyari' atkannya setiap perintah dan larangan dalam agama Islam. Penggunaannya sebagai spirit dalam penetapan hukum, telah dipraktekkan sejak masa hidup Rasulullah SAW, era sahabat, dan periode tabi'in. Sekalipun demikian, eksistensinya sebagai sebuah objek kajian ilmiah maupun sebagai sebuah aspek pertimbangan perumusan hukum, baru dimulai sekitar akhir abad $3 \mathrm{H}$ adalah al Hakim at Turmudzi, yang dianggap sebagai orang yang pertama menggunakan istilah 'maqashid' dan menjadikannya sebagai sebuah objek kajian ilmiah, yang mewujud dalam sebuah kitab karya beliau al Shalat wa Maqashiduha (Raisuni, 2003: 5).

Pada tahapan selanjutnya, perkembangan kajian mengenai maqashid al Syariah mengalami progress yang sangat signifikan. Eksistensi maqashid al Syariah bukan hanya sebatas objek kajian ilmiah maupun spirit dalam hukum, tapi lebih jauh telah menjadi sebuah pendekatan dalam perumusan hukum itu sendiri. Karena implikasinya yang sangat besar ketika eksis sebagai sebuah pendekatan atau filsafat hukum, maka perlu adanya standarisasi penggalian dan penggunaannya. Hal ini diorientasikan agar pendekatan maqashid tidak dioperasionalkan secara liar dan out of control, sehingga melahirkan produk ijtihad dan kebijakan hukum yang spekulatif dan serampangan. Atas dasar pertimbangan ini, para ulama secara sadar sebagai tanggungjawab etika-ilmiah, merumuskan aturan-aturan khusus sebagai bentuk penertiban dalam upaya mendeteksi keberadaan maqashid al Syariah dalam kandungan setiap aturan syari'at, sekaligus menetapkannya dalam status layak atau tidak untuk digunakan sebagai dasar pertimbangan perumusan dan istinbath hukum.

Adapun yang hendak diungkap dalam kajian ini adalah bagaimana metode melacak, mendeteksi, dan mengetahui keberadaan maqashid al Syariah dalam kandungan setiap ketetapan syari'at, serta bagaimana metode penetapan maqashid al Syariah dalam operasionalisasinya sebagai pendekatan dan dasar pertimbangan perumusan hukum, dari perspektif Abu Ishaq al Syatibi.

Mengenai kajian thuruq al itsbat li al maqashid al Syariah, terdapat beberapa terminologi yang digunakan para ulama seperti maslak al kasyf ala al maqashid, subul itsbat al maqashid, thuruq kasyf wa ta'yin al maqashid, dan lainnya (al Khadimi, 2001: 67).

\section{Sekilas Tentang Abu Ishaq Al Syatibi}

Untuk mendapatkan gambaran kesejarahan al Syatibi, khususnya berkaitan 
dengan perkembangan ilmu pengetahuan. Banyak penulis sejarah menduga bahwa ia berada di Granada Spanyol pada masa pemerintahan Ismail Ibnu Farraj yang berkuasa tahun $713 \mathrm{H}$, Muhammad Ibnu Ismail yang berkuasa tahun 725 H, Abu Hajjaj Ibnu Yusuf Ibnu Ismail yang berkuasa tahun 734 $\mathrm{H}$, dan Muhammad al Ghani bi Allah Ibnu Abi Hujjaj Yusuf yang berkuasa tahun 755 H. Latar belakang kehidupan keluarga al Syatibi belum banyak diketahui orang, yang jelas keluarganya berasal dari kota Syatibah (Jativa). Nama lengkap al Syatibi adalah Abu Ishaq Ibrahim Ibnu Musa al Gharnati al Syatibi. Ia meninggal dunia pada tahun $790 \mathrm{H}$, namun ia sendiri tidak lahir di negeri asal keluarganya, sebab kota Syatibah telah jatuh ke tangan penguasa Kristen, semua penduduk yang beragama Islam diusir dari Syatibah dan sebagian besar mereka melarikan diri ke Granada (al Maraghi, 1974: 204). Sehingga dapat diduga keluarganya bermukim sebagai penduduk Granada sampai akhir hayatnya. Kehidupan politik dalam negeri Granada pada masa al Syatibi berada dalam keadaan yang tidak stabil. Perpecahan dan pertentangan dalam negeri berlangsung cukup lama, hal ini memberikan kemudahan bagi kekuatan Kristen untuk melakukan penyerangan (al Ajfan, 1985: 26).

Meskipun dalam kehidupan sosial politik yang tidak stabil, ternyata tidak menyebabkan terjadinya kemunduran bidang ilmu pengetahuan dan perkembangannya, sehingga pada masa al Syatibi telah berdiri dua buah yayasan ilmu pengetahuan, yaitu yayasan masjid besar yang menyelenggarakan pendidikan, gurunya antara lain Abu Said Farraj Ibnu Lub, dan yayasan Nashiriyyat yang didirikan oleh sultan Abu Hujjaj Yusuf pada pertengahan abad ke delapan Hijriyah sebagai bukti berkembangnya kehidupan ilmiah, meskipun banyak kota di bawah kekuasaan Kristen, para ulama dan pengarang terus membangun kehidupan ilmiah. Ilmuwan-ilmuwan yang muncul antara lain Ibnu Juzai, Ibnu Lub, Ibnu Fakhkhar, Ibnu Jayyab dan Ibnu Asim dalam bidang ilmu fikih. Ibnu Abi Hayyan, Ibnu Sha'ig dalam bidang ilmu nahu. Ibnu Khatib, Zamrak dan Ibnu Asim dalam bidang ilmu kalam dan siasah. Ibnu Huzail al Hakim dalam bidang filsafah dan al Syatibi dalam bidang ushul fikih dan falsafah Syariah (al Ajfan, 1985: 30).

Pada masa itu Granada menjadi pusat kegiatan ilmiah dengan berdirinya Universitas Granada, sehingga Granada pada masa itu hampir dapat disamakan dengan Cordova di masa filosof dan faqih ternama Ibnu Rusyd pada tahun 594 H (K. Hitti, 1974: 563). Istana Hamra yang didirikan oleh Muhammad Ibnu Ahmar sebagai bukti kesamaannya dengan Cordova yang merupakan puncak kemegahan arsitektur Islam di Spanyol. 
Kemajuan yang dicapai pada abad ke-8 $\mathrm{H}$ layak disebut mengagumkan karena di tengah-tengah kemunduran dan kekacauan politik serta munculnya kecenderungan besar umat Islam melakukan bid'ah dan khurafat, maka dalam suasana seperti itu Mustafa Ahmad Zarqa menyatakan bahwa pada masa yang berat itu ternyata melahirkan tokoh besar Ibnu Taimiyah $(661 \mathrm{H})$ dan Ibnu Qayyim al Jauziyah $(751 \mathrm{H})$ di dunia Islam belahan timur, serta Ibnu Khaldun $(732 \mathrm{H})$ dan Abu Ishaq al Syatibi $(790 \mathrm{H})$ di dunia Islam belahan Barat (al Ajfan, 1985: 8).

Karya-karya ilmiah al Syatibi dibagi menjadi dua kelompok, pertama, karya-karya yang tidak diterbitkan dan dipublikasikan, antara lain: Syarh Jalil 'ala al Khulashah fi al Nahwi, Khiyar al Majalis (syarah kitab jual beli dari sahih al Bukhari), Syarh Rajz Ibnuu Malik fi al Nahwi, 'Inwan al Ittifaq fi 'Ilmi al Isytiqaq, dan Usul al Nahw. Kedua, karya-karya yang diterbitkan dan dipublikasikan, yaitu al Muwafaqat $f i$ Ushul al Syariah, al I'tisam, dan al Ifadat wa al Irsyadat (al Ajfan, 1985: 43-44). Kitab al Muwafaqat merupakan karya besar al Syatibi dalam bidang usul fikih, yang berusaha memaparkan kajian secara mendalam mengenai rahasia-rahasia pentaklifan dan tujuan pensyari'atan hukum Allah dan aspek-aspek lain dari kajian usul fikih terutama pada kajian maqasid al Syariah.

\section{Definisi dan Konsep Maqashid Al Syariah}

Maqashid al Syariah atau Maqashid al Syari' adalah nama dan laqob sebuah disiplin ilmu dari sekian bentuk keilmuan yang ada pada kajian syari'at Islam, yang dalam kajian bahasa, istilah maqashid al Syariah itu tersusun dari dua lafazd (kata), yaitu kata maqashid dan kata al Syariah (al Youbiy, 1998: 25). Agar dapat memperoleh informasi yang mendalam dan kajian yang komprehensif tentang maqashid al Syariah, paling tidak harus mengupas dan membedah kajian kebahasaan yang ada pada dua istilah, yaitu; istilah maqashid, dan istilah al Syariah.

Secara bahasa (etimologi) kata maqashid (المقاصد) adalah bentuk plural (jama') dari kata maqshad (المقَصَد). Kata maqshad (المقصد)) sendiri adalah bentuk masdhar mim (مصدر ميهم) dari kata kerja qashada yaqshidu qasdhan wa

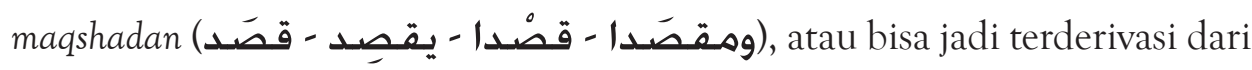
isim makan al Maqshid (المقصدي) (al Khadimi, 2001: 13). Untuk memperoleh arti dari kata tersebut, maka harus mengetahui dan menjelajah lebih lanjut 
tentang penggunaannya dalam kajian bahasa Arab, diantaranya, kata tersebut memiliki beberapa makna dan arti, yaitu: Pertama, bermakna al I'tizam, al I'timad, wa Thalab al Syai'i wa Ityanuh (الاعتزام, والاعتماد, والام, وطلب (الشيسئ واتيانه dan mendatanginya, kata tersebut sebagaimana digunakan dan dipakai dalam suatu redaksi hadits Nabi SAW yang berbunyi; فقصدت لعثنمان حتى خـرج هـ الصـلاة. diantara sekian makna dan arti yang ada, kata inilah yang lebih mendekati makna atau makna pokok/asal untuk kata tersebut (al Badawiy, 1999: 43).

Kedua, bermakna Istiqamat al Thariq (اسـتقامة الطريق) yang berarti jalan yang lurus, hal tersebut sebagaimana penggunaannya pada QS an Nahl ayat 09; وعلى الله قصد السـبيل maksudnya (وعلى الله تبين الطريق القصد من الطريق :al Kailaniy, 2000: 44). Ibnu Jarir berkata) (المستقيم المستقيـيم الذي لا اعوجـاج فيـ , yang secara bebas dapat difahami, bahwa kata al Qashdu dapat bermakna jalan lurus yang tidak ada bengkokan padanya (al Youbiy, 1998: 25).

Ketiga, al qashdu yang bermakna adil, tawassud dan 'adam al ifrad (العـلرل) (التوسـط, عدم الافراد , sebagaimana itu banyak digunakan dalam syair, sedangkan yang bermakna tawassud dan 'adam ifrad, sebagaimana dipakai dalam QS Lukman ayat 19, yang berbunyi; واقصد في مشـيك (أي أمشيك (مشيـة مسـتوية (al Badawiy, 1999: 43). Sebagai pendukung arti ini pula, sebuah redaksi hadits yang riwayatkan oleh Jabir bin Samrah

$$
\text { كنـت أصلى مـع رسـول الله, فكـانت صـلاته قصدا وخطبتـه قصـدا, اي }
$$
وسـا بين الطويلة والقصيرة (al Youbiy, 1998: 285) .

Keempat, bermakna al Kasr fi ayyi wajhin kana, atau memecah dalam bentuk atau keadaan apapun, sebagaimana seandainya dikatakan, qashadtu al 'auda qasdhan kasartuhu.

Kelima, bermakna al Iktinaz fi al Syay'I (الاكتناز في الشيسي) yang الناقة الن unta yang gemuk yang penuh dengan daging (Aziz, 2002: 19). 
Keenam bermakna al qurbu (dekat), sebagaimana dikatakan dalam kalam Arab, بينـا وبين الماء ليلة قاصدة, اي هينة السير, dalam QS At

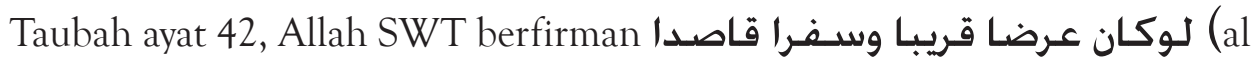
Badawiy, 1999: 44).

Selanjutnya maqashid dari sisi terminologis, mengandung pengertian; sebagai sesuatu yang dikehendaki dari proses pentasyri'an beberapa hukum, atau dapat dikatakan juga, bahwa yang dimaksud maqashid adalah keinginan tercapainya sesuatu yang dikehendaki dari sebuah pentasyri'an hukum (Aziz, 2002: 20). Sedangkan istilah kedua yang harus dipahami adalah syari' at, atau dalam bahasa lain disebut dengan syara' dan Syariah yang secara bahasa memiliki arti sumber dan tempat munculnya air, ada juga yang mengatakan Syariah secara bahasa adalah jalan menuju mata air atau dalam istilah lain dikatakan dengan istilah al Millah, al Dien, al Thariqah, al Minhaj dan al Sunnah (Mawardi, 2012: 179). Adapun pendefinisian Syariah sebagai sumber air adalah sebuah perumpamaan sesungguhnya Syariah dan agama adalah sumber (masdhar) jiwa (manusia, hewan, tumbuhan) dalam hal untuk memperoleh kemajuan, keberuntungan dan keselamatan di dunia dan akhirat, sebagaimana hal tersebut dijelaskan al Quran dalam QS al Anfal ayat 24 (al Khadimi, 2001: 14).

Ada juga sebagian ulama' mendefinisikan Syari'at dengan, suatu ketentuan hukum yang disyari'atkan Allah SWT terhadap hamba-Nya agar dengan tuntunan syari'at hamba-Nya mendapatkan petunjuk, atau dengan ungkapan lain syari'at adalah suatu ketentuan hukum yang terangkum dan bersumber dari al Quran dan al Hadits. Dalam terminology fiqh, syariat bermakna hukum-hukum yang disyari'atkan Allah SWT untuk hamba-Nya, baik yang ditetapkan menurut al Quran maupun sunnah Nabi SAW yang berupa perkataan, perbuatan dan ketetapan nabi SAW. Dalam definisi yang lebih singkat dan umum dinyatakan bahwa Syariah bermakna sejumlah hukum amaliyah yang dibawa oleh agama Islam, baik yang berkaitan dengan konsepsi aqidah, maupun legislasi hukumnya (al Raysuni, 1999: 10).

Selanjutnya akan kami hantarkan beberapa definisi, baik yang telah di sampaikan oleh pakar maqashidi murni atau ahli hukum Islam, baik dari kalangan klasik atau kalangan kontemporer. Namun sebelumnya harus diketahui, bahwa makna maqashid al Syariah berkembang dari makna yang paling sederhana sampai pada makna yang holistic. Di kalangan ulama' klasik sebelum al Syatibi sendiri, sebenarnya belum ditemukan definisi yang kongkret dan komprehensif tentang maqashid al Syariah. Definisi mereka cenderung mengikuti 
makna bahasa dengan menyebutkan padanan-padanan maknanya. Al Bannani memaknainya dengan hikmah hukum, al Asmawi mengartikannya dengan tujuan-tujuan hukum, al Samarqandi menyamakannya dengan makna-makna hukum, sementara al Ghazali, al Amidi, dan Ibnu Hajib mendefinisikannya dengan menggapai manfaat dan menolak mafsadat (Umar, 2003: 88).

Untuk lebih jelasnya, berikut adalah contoh definisi maqashid al Syariah oleh ulama klasik, al Ghazali mendefinisikan sebagai berikut:

"Maslahah adalah sebuah istilah yang pada intinya merupakan keadaan yang mendatangkan manfaat dan menolak bahaya atau kerugian. Yang kami maksudkan sebenarnya bukan ini, karena mendatangkan manfaat dan menolak bahaya atau kerugian adalah tujuan makhluq. Kebaikan makhluk adalah ketika menggapai tujuan-tujuannya. Yang kami maksudkan dengan maslahah di sini adalah menggapai tujuan syara'. Tujuan syara' untuk makhluk ada lima, yaitu; menjaga agama, jiwa, akal, keturunan dan harta mereka" (al Badawi, 1999: 46).

Sementara itu Saifuddin Abu al Hasan Ali bin Abi Ali bin Muhammad al 'Amidi mendefinisikan lebih singkat, yaitu tujuan syari'at adalah mendatangkan kemaslahatan atau menolak kemafsadatan atau kombinasi keduanya. Definisi ini sangat umum, konsepsional, dan abstrak sehingga belum dapat dibayangkan bagaimana cara menentukannya. Definisi yang lebih tegas dan operasional dikemukakan oleh al 'Izz bin Abd al Salam;

"Barang siapa yang berpandangan bahwa tujuan syara' adalah mendatangkan manfaat dan menolak mafsadat, maka berarti dalam dirinya terdapat keyakinan dan pengetahuan yang mendalam bahwa kemaslahatan dalam suatu permasalahan tidak boleh disia-siakan sebagaimana kemafsadatan yang ada di dalamnya juga tidak boleh didekati walaupun dalam masalah tersebut tidak ada ijma', nash dan qiyas yang khusus" (al Badawi, 1999: 46).

Gambaran tersebut memperlihatkan suatu perkembangan dari masa ke masa, baik dari sisi cakupan maupun penekanannya. Definisi singkat tapi operasional yang menghubungkan antara Allah dan pembagian maqashid al Syariah dalam susunan yang hirarkis didapatkan pada perkembangan berikutnya yang dipelopori oleh Abu Ishaq al Syatibi, tokoh yang dikukuhkan sebagai pendiri ilmu maqashid al Syariah, al Syatibi menyatakan bahwa:

"Beban beban syariat kembali pada penjagaan tujuan-tujuannya pada makhluk. Maqashid ini tidak lebih dari tiga macam; dharuriyyat (kepentingan pokok), hajiyat (kepentingan sekunder) dan tahsiniyyat (kepentingan tersier). Lebih lanjut al Syatibi menyatakan bahwa Allah sebagai syari' memiliki tujuan dalam setiap penentuan hukumnya, yaitu untuk kemaslahatan hidup di dunia dan akhirat" (al Badawi, 1999: 46). 
Sepeninggal al Syatibi kajian maqashid al Syariah menemui kebuntuan yang cukup lama, terpendam sekitar enam abad dalam kejumudan intelektual, sampai hadirnya Muhammad Thahir bin Asyur yang mengangkat kembali kajian maqashid al Syariah sebagai disiplin keilmuan yang mandiri. Ibnu Asyur mengatakan bahwa semua hukum Syariah tentu mengandung maksud dari syari', yakni hikmah, kemaslahatan dan manfaat, dan bahwa tujuan umum syari'at adalah menjaga keteraturan umat dan kelanggengan kemaslahatan hidup mereka. Lebih lanjut Ibnu Asyur mendefinisikan maqashid al Syariah sebagai berikut;

"Makna-makna dan hikmah-hikmah yang diperhatikan dan dipelihara oleh syari' dalam setiap bentuk penentuan hukumnya. Hal ini tidak hanya berlaku pada jenis-jenis hukum tertentu sehingga Syariah yang terkandung dalam hukum serta masuk pula di dalamnya makna-makna hukum yang tidak diperhatikan secara keseluruhan tetapi dijaga dalam banyak bentuk hukum".

Definisi yang dikemukan oleh Ibnu Asyur ini sudah mulai masuk pada wilayah yang lebih kongkrit dan operasional. Sebagai penegasnya dia juga menyatakan bahwa maqashid al Syariah bisa saja bersifat umum yang meliputi keseluruhan syariat dan juga dapat bersifat khusus, seperti maqashid al Syariah yang khusus pada bab-bab mu'amalah. Dalam konteks ini maqashid al Syariah diartikan sebagai kondisi-kondisi yang dikehendaki oleh syara' untuk mewujudkan kemanfaatan bagi kehidupan manusia atau untuk menjaga kemaslahatan umum dengan memberikan ketentuan hukum dalam perbuatan-perbuatan khusus mereka yang mengandung hikmah. Dalam kajian yang lebih mendalam, Ibnu Asyur adalah tokoh yang mumpuni di bidang maqashid (Thahir, 2001: 189-190).

Sedangkan menurut 'Alal al Fasi maqashid al Syariah didefinisikan dengan; tujuan dan rahasia yang ditetapkan pada setiap hukum syari'at (al Fasi, 1993: 7). Sedangkan menurut Ahmad Raisuni adalah tujuan yang dijadikan target oleh al Syari', untuk kemaslahatan umat manusia (al Khalifi, 2004: 8).

Dari beberapa pendapat yang telah disampaikan di muka, dapat dirangkai sebuah definisi dan pengertian yang utuh tentang Maqashid al Syariah (al Islamiyah) sehingga menjadi konsep yang sempurna, yaitu: sebuah ilmu yang di dalamnya memuat makna dan hikmah yang dikehendaki oleh al syari' dari pentasyri'an hukum dalam rangka mewujudkan kemaslahatan makhluk, baik ketika di dunia maupun di akhirat. 


\section{Metode Mengetahui Maqashid Al Syariah}

Langkah pertama yang harus ditempuh serangkaian dengan penggunaan maqashid al Syariah sebagai aspek pertimbangan, landasan, dan pendekatan perumusan hukum, adalah mendeteksi dan mengetahui (al ma'rifah) eksistensi maqashid al Syariah itu sendiri. Hal ini sangat penting untuk meminimalisir penetapan maqashid al Syariah secara liar berdasarkan klaim-klaim spekulatif dan tidak berdasar sebagai basis ijtihad (Habib, 2003: 36-37).

Secara umum, Imam Al Ghazali menyatakan bahwa maqashid al Syariah dapat diketahui dari keterangan-keterangan al Quran, as Sunnah, dan al Ijma' (al Ghazali, 1413: 502).

Terkait dengan kajian al Quran, yang sangat dibutuhkan dalam mendeteksi dan memahami maqashid al Syariah adalah penghayatan hikmah-hikmah ayatayat suci (tadabbur) serta pendalaman melalui kitab-kitab tafsir al Quran yang mu'tabar. Demikian halnya untuk mengetahuinya lewat as sunnah, dengan mengkaji lebih dalam kitab-kitab hadits sahih, kitab-kitab sunan, masanid, jawami', dan syarah-syarah hadits yang diakui kualitasnya.

Lebih lanjut, Izzuddin bin Abdissalam membedakan pendekatan dalam mendeteksi dan memahami maqashid al Syariah berdasarkan objek kajiannya. Untuk mendeteksi dan memahami maqashid (maslahat dan mafsadat) yang bersifat diniyah, tidak ada jalan lain untuk mewujudkannya kecuali melalui keterangan-keterangan normatif (naqli) baik dari al Quran, as Sunnah, al Ijma, al Qiyas al Mu'tabar, dan al Istidlal al Sahih (Izzuddin, 2000: 13). Sementara untuk maslahat yang bersifat duniawiyah, pendekatannya boleh berdasarkan dalil logika (aqli) dan optimalisasi penggunaan nalar dan rasio yang benar melalui serangkaian eksperimen, kebiasaan empirik, kumpulan hipotesa, dll. Hal ini sebagaimana diisyaratkan beliau dalam kitabnya:

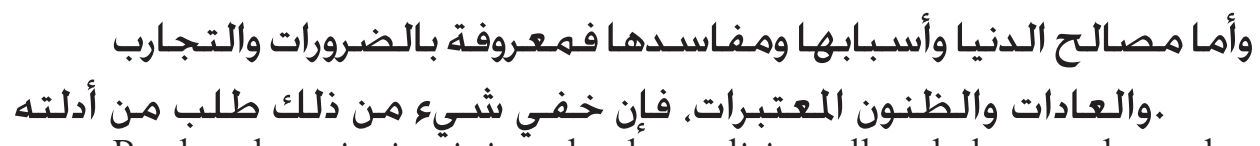

Berdasarkan rincian ini, maka dapat disimpulkan bahwa terdapat dua cara untuk mendeteksi dan memahami maqashid al Syariah, yaitu dengan pendekatan normatif (berdasarkan keterangan al Quran, al Sunnah, dan al Ijma) dan pendekatan logis rasional (dengan memaksimalkan nalar berdasarkan kaidah berfikir yang benar).

\section{Metode Penetapan Maqashid Al Syariah Menurut Abu Ishaq Al Syathibi}

Metode penetapan (thuruq al itsbat) maqashid al Syariah, pada hakikatnya 
merupakan penjelasan teknis dan opersionalisasi lanjutan dari cara menyingkap (thuruq al ma'rifah) maqashid al Syariah. Ulama berbeda-beda dalam rumusan metodologi penetapan maqashid. Perbedaan ini ada yang bersifat perbedaan substantsi kebahasaan, dan ada berupa perbedaan terminologi. Berikut beberapa rumusan para pakar mengenai thuruq al itsbat li al maqashid al Syariah.

Sementara al Syathibi merumuskan bahwa penetapan maqashid Syariah dapat ditempuh melalui empat metode berikut:

1. Mujarrad al amr wa an nahy al ibtida'i at tasrihi

Secara sederhana, metode ini dapat dipahami sebagai sebuah upaya melihat ungkapan eksplisit perintah dan larangan dalam nash, yang eksistensi kedua unsur tersebut ada secara mandiri (ibtidai). Sebagaimana dipahami, suatu perintah menuntut ditunaikannya perbuatan yang diperintahkan, sementara suatu larangan menuntut dijauhinya perkara yang dilarang. Maka terwujudnya perbuatan yang dikehendaki perintah syari'at, atau tercegahnya perkara yang dilarang, dapat disimpulkan berkesesuaian dengan kehendak Allah SWT (maqshud asy syari'). Bila yang terjadi adalah hal yang sebaliknya, perkara yang diperintahkan tidak terlaksana, atau perkara yang dilarang justru tetap dilaksanakan juga, maka hal itu dianggap menyelisihi maqshud asy syari' (al Syathibi, tt: 393).

Dengan demikian, penetapan dengan cara ini bisa dikategorikan sebagai penetapan berdasarkan literal nash, yang dibingkai dengan pemahaman umum bahwa dalam perintah syari'at pasti terdapat unsur maslahat dan dalam setiap larangan pasti ada unsur mafsadat.

Sekalipun demikian, bila menilik redaksi yang diungkap oleh Imam Syatibi, terindikasi dua syarat operasional yang dikemukakan, yaitu: Pertama, Perintah dan larangan itu diungkapkan secara eksplisit dan mandiri (ibtidai) Berdasarkan syarat ini, maka perintah yang sifatnya penguat saja tidak bisa digunakan dalam metode ini. Misalnya, larangan jual beli dalam firman Allah SWT dalam surat al Jum'ah ayat 9:

"bukan merupakan larangan jual beli secara murni dan mandiri (ibtida'i), melainkan sebatas larangan untuk menguatkan perintah as sa'yu ila adz dzikr (bersegera untuk melaksanakan shalat jum'at)".

Kedua, perintah dan larangan itu harus diungkapkan secara eksplisit (sarih) Dengan adanya syarat ini, maka perintah dan larangan yang bersifat dhimni, atau yang dipahami dari mafhum an nushush (seperti mafhum muwafaqah dan mukhalafah, dll), maupun yang dipahami dari kaidah-kaidah fiqih (seperti ma la yatimm al wajib illa bihi fa huwa wajib, atau alarm bi asy syai' nahyun an 
dhiddih, dll), tidak bisa digunakan untuk menetapkan maqashid al Syariah berdasarkan pendekatan ini.

2. Memperhatikan konteks illat dari setiap perintah dan larangan

Metode ini pada hakikatnya masih memiliki keterkaitan erat dengan metode pertama, tetapi titik fokusnya lebih pada pelacakan illat di balik perintah dan larangan. Pada tataran ini, penetapan maqashid berangkat dari pertanyaan-pertanyaan mendasar tentang ada apa di balik perintah dan larangan itu? Mengapa perkara ini diperintahkan? Mengapa hal itu dilarang? Dengan pembahasan ini, al Syatibi tidak menjadikan illat sebagai maqashid itu sendiri, melainkan sebatas alamat atau isyarat yang mengarahkan kepada maqashid. Adapun yang dijadikan maqashid adalah konsekwensi ideal dari illat (muqtadha al ilal) dari sisi terlaksananya perbuatan yang diperintahkan dan tercegahnya perkara yang dilarang (Izzuddin, 1996: 118).

Illat dibedakan menjadi dua, yaitu illat yang diketahui (ma'lumah) dan illat yang tidak diketahui (ghairu ma'lumah). Illat ma'lumah, wajib untuk diikuti oleh seorang mujtahid dalam proses ijtihadnya, berdasarkan kaidah-kaidah masalik al illat yang banyak dibahas dalam ilmu ushul fiqh. Adapun illat ghairu ma'lumah, sikap yang wajib diambil adalah tawaqquf, serta tidak secara gegabah dan spekulatif memutlakkan klaim bahwa yang dikehendaki Allah SWT adalah begini dan begitu.

Sebab dipilihnya sikap tawaqquf terhadap illat ghairu ma'lumah karena dua hal, yaitu: Pertama, tawaqquf karena ketiadaan dalil yang menunjukkan illat dalam nash. Kedua, tawaqquf karena sekalipun ada illat yang manshush, tetapi bisa jadi bukan merupakan maqshud asy syari' (al Syathibi, tt: 394-395).

\section{Memperhatikan semua maqashid turunan (at tabi'ah)}

Semua ketetapan syari'at, ibadah maupun mu'amalah, memiliki tujuan yang bersifat pokok (maqshud al ashli) dan yang bersifat turunan (maqashid at tabi'ah). Dalam syari'at nikah misalnya, yang menjadi maqshud al ashli adalah kelestarian manusia lewat perkembang-biakan (at tanasul). Sementara setelahnya, terdapat beberapa maqashid turunan (tabi'ah) seperti mendapatkan ketenangan (as sakinah), tolong-menolong dalam kemaslahatan duniawi dan ukhrawi, penyaluran hasrat biologis manusiawi (al istimta') secara halal, membentengi diri dari terpaan fitnah, dll, semua itu merupakan akumulasi dari maqashid at tabi'ah dalam syari'at nikah. 
Dari semua maqashid itu, ada yang diungkapkan secara eksplisit oleh nash (manshush), ada yang sebatas isyarat yang mengindikasikan kepada maqashid, dan ada pula yang dipahami dari dalil-dalil lain atau disimpulkan berdasarkan penelusuran secara induktif (maslak al istiqra') dari nash-nash yang ada. Maka keberadaan semua maqashid yang bersifat turunan ini dianggap sebagai kehendak Allah (maqshud asy syari') yang berfungsi untuk menguatkan dan menetapkan eksistensi maqshud al ashli. Bahkan lebih jauh, semua maslahat yang muncul secara empirik dari syari'at nikah sekalipun tidak manshush, diposisikan sebagai penguat terhadap maqshud ashli. Dengan demikian, semua hal yang bertentangan terhadap semua maqashid baik ashli maupun tabi'ah, baik maslahat yang manshush maupun maslahat yang empirik, dianggap menyelisihi maqshud asy syari'.

\section{Tidak adanya keterangan syar'i (sukut asy sayri')}

Maksud dalam bahasan ini adalah tidak adanya keterangan nash mengenai sebab hukum atau disyari'atkannya suatu perkara, baik yang memiliki dimensi ubudiyah maupun mu'amalah, padahal terdapat indikasi yang memungkinkan terjadinya perkara tersebut pada tataran empirik. Secara rinci, cakupan perkara yang tidak ada keterangan syar'i ini dipetakan pada dua jenis:

a. Ketiadaan keterangan karena belum adanya kebutuhan tasyri' untuk menjelaskannya.

Persoalan yang masuk dalam kategori ini adalah semua persoalan baru yang muncul (an nazilah) setelah wafatnya Rasulullah. Karena pada hakikatnya, hal itu belum eksis pada masa tasyri' ketika Rasulullah SAW masih hidup (seperti kodifikasi al Quran, pembukuan ilmu pengetahuan, dll). Terkait dengan hal ini, upaya mengetahui dan menetapkan maqashid-nya adalah dengan mengembalikan furu' kepada ushul yang relevan, atau dengan menelusuri nash-nash yang memiliki keterkaitan dan menyimpulkannya secara induktif atau al istiqra' (al Syathibi, tt: 409-410)

b. Perkara yang telah berkemungkinan ada di masa tasyri', tetapi tidak ada keterangan syari'at terhadapnya.

Permasalahan ini lebih terkait dengan hal hal berdimensi ubudiyah. Dalam hal ini, persoalannya dipetakan kepada tiga bagian (al Syathibi, tt: 411):

1. Mengerjakan sesuatu yang tidak ada keterangan syari'at terhadap status pelaksanaannya, atau meninggalkan sesuatu yang diizinkan oleh syari'at. Seperti sujud syukur, do'a berjama'ah setelah shalat, berkumpul untuk 
berdo'a ba'da ashar pada hari arafah bagi yang sedang tidak wuquf di arafah, dll.

2. Mengerjakan sesuatu yang tidak ada dalil syari' at terhadap izin pelaksanaannya, atau meninggalkan sesuatu yang diizinkan syari'at. Misalnya, berpuasa sambil menahan diri dari berbicara, atau riyadhah nafsiyah dengan meninggalkan makanan halal tertentu.

3. Melakukan sesuatu yang tidak ada keterangan syari'at, tetapi hal itu menyelisihi ketetapan syari'at yang lain. Misalnya, mewajibkan berpuasa dua bulan berturut-turut dalam kafarat dzihar, bagi orang yang mampu memerdekakan budak.

4. Menyikapi ketiga perkara ini, al Syathibi menggolongkan perkara yang ketiga ke dalam bentuk menyelisihi ketetapan nash syari'at dan termasuk dalam kategori bid'ah qabihah (al Syathibi, tt: 411).

Adapun untuk dua hal sebelumnya, al Syathibi berpendapat bahwa sesuatu yang didiamkan syari'at tidak secara otomatis melaksanakannya dihukumi bertentangan dengan syari'at. Maka yang harus dilakukan dalam menjernihkan permasalahan ini adalah mendeteksi dimensi maslahat dan mudharat di dalamnya. Bila terindikasi adanya maslahat, maka hal itu bisa diterima. Sebaliknya bila terdeteksi dimensi mudharat di dalamnya, secara otomatis hal itu tertolak. Dengan demikian, teknik operasional yang digunakan dalam menyikapi persoalan seperti ini adalah pendekatan al maslahah al mursalah (al Syathibi, tt: 412).

\section{Simpulan}

Dari kajian sederhana dalam pembahasan tulisan ini, dapat ditarik simpulan berikut:

1. Thuruq ma'rifat maqashid al Syariah, pendekatannya dibedakan berdasarkan objek kajiannya. Untuk maqashid diniyah, pendekatannya melalui sinkronisasi dalil-dalil naqli dan aqli. Sementara untuk maqashid diniyahukhrawiyah, pemahamannya mutlak hanya dengan pendekatan dalil naqli saja. Dengan bahasa lain, terdapat dua cara untuk mendeteksi dan memahami maqashid al Syariah, yaitu pendekatan normatif (berdasarkan keterangan al Quran, al Sunnah, dan al Ijma) dan pendekatan logis rasional (dengan memaksimalkan nalar berdasarkan kaidah berfikir yang benar).

2. Menurut al Syathibi, ada empat cara yang dapat digunakan sebagai metode penetapan maqashid al Syariah, yaitu: Pertama, mujarrad al amr wa an nahy al 
ibtida'i at tasrihi. Kedua, memperhatikan konteks illat dari setiap perintah dan larangan. Ketiga, memperhatikan semua maqashid turunan (at tabi'ah). Keempat, tidak adanya keterangan syar'i (sukut asy sayri').

\section{Daftar Pustaka}

Thahir, Muhammad bin Asyur. 2001. Maqashid al Syariah al Islamiah. Yordania: Dar al Nafais.

Izzuddin bin Abdissalam. 2000. Qawa'id Ahkam fi Mashalih al Anam atau al Qawaid al Kubro. Damaskus: Dar al Qalam.

Al Badawiy. Yusuf Ahmad. 1999. Maqashid al Syariah 'Inda Ibnu Taimiyyah. Yordania: Dar al Nafais.

Al Fasi, Abu 'Alal. 1993. Maqashid al Syariah al Islamiyah wa Makarimaha. Dar al Gharb al Islami.

Al Ghazali, Abu Hamid. 1413. Al Mustashfa min Ilmi al Ushul. Madinah: Al Jami'ah al Islamiyah al Madinah al Munawarah.

Al Kailaniy, Abdurrahman Ibrahim. 2000. Qawaid al Maqashid 'inda al Imam al Syatibiy 'Ardhan wa Dirasatan wa Tahlilan. Damaskus: Dar al Fikr.

Al Khadimi, Nuruddin. 2001. Ilmu al Maqashid al Syar'iyah. Riyadh: Maktabah al Ubaikan.

Al Khalifi, Riyadh Manshur. 2004. Al Maqashid al Syar'iyyah wa Atsaruha fi Figh al Mu'amalat. Mekkah.

Al Syathibi, Abu Ishaq. tt. Al Muwafaqat fi Ushul al Syariah. Mesir: Maktabah al Tijariyah al Kubra.

Al Youbiy, Muhammad bin S'ad bin Ahmad bin Mas'ud. 1998. Maqashid al Syariah wa 'Alaqatuha bi al Adillah al Syar'iyyah. Riyadh: Dar al Hijrah.

Habib, Muhammad Bakr Ismail. 2003. Maqashid Asy Syariah Ta'shilan wa Taf'ilan. Makkah: Rabithah al Alam al Islami.

Izzuddin Bin Zughaibah. 1996. Al Maqashid al Ammah li al Syari'at al Islamiyah. Kairo: Dar al Shafwah.

Mawardi, Ahmad Imam. 2012. Fiqh Minoritas Fiqh al Aqalliyat dan Evolusi Maqashid al Syariah dari konsep ke pendekatan. Jogjakarta: LKIS. 
Aziz, Abdul bin Abdurrahman bin Ali bin Rabi'ah. 2002. Ilmu Maqashid al Syariah. Riyadh: al Mamlakah al 'Arabiyyah al Saudiyyah.

Raisuni, Ahmad. 1995. Nadhariyat al Maqashid 'inda al Imam al Syatibi. Virginia: The International Institute of Islamic Thought.

Raisuni, Ahmad. 1999. Al Fikr al Maqashidi Qawaiduh wa Maqashiduh. Riyadh: Mathba'ah al Najah al Jadidah al Dar al Baidha'.

Raisuni, Ahmad. 2003. Makalah Forum Ilmiah Internasional tentang Maqashid Syariah. Al Bahts fi Maqashid Asy Syariah: Nasy'atuh wa Tathawwuruh wa Mustaqbaluh. London: Muassasah Al Furqan li At Turats.

Raisuni, Ahmad. Muhadharah Fi maqashid al Syariah: Ta'rifat wa Muqaddimah. Http. //www. raisuni.org.

Umar bin Shalih bin Umar. 2003. Maqashid al Syariah 'Inda al Imam al 'Izz bin Abd al Salam. Urdun: Dar al Nafais li al Nasyr wa al Tauzi'. 